\title{
Agronomic performance of AR37-infected ryegrass in northern New Zealand
}

\author{
D.E. HUME ${ }^{1}$, D.L. RYAN ${ }^{2}$, B.M. COOPER ${ }^{3}$ and A.J. POPAY ${ }^{2}$ \\ ${ }^{1}$ AgResearch, Grasslands Research Centre, Private Bag 11008, Palmerston North 4442, New Zealand \\ ${ }^{2}$ AgResearch, Ruakura Research Centre, Private Bag 3123, Hamilton 3240, New Zealand \\ ${ }^{3}$ AgResearch, Kerikeri Research Centre, PO Box 23, Kerikeri 0245, New Zealand
}

david.hume@agresearch.co.nz

\begin{abstract}
The agronomic merits of a perennial ryegrass (Lolium perenne) cultivar infected with a new endophyte (Neotyphodium lolii), AR37, were compared with the same cultivar infected with currently available endophytes (AR1, Standard) at two sites in northern New Zealand for at least 3 years. AR37-infected ryegrass was the highest yielding treatment at both sites $(11080 \mathrm{~kg} \mathrm{DM} /$ ha/yr) producing more dry matter than either AR1 or Standard-infected ryegrass which yielded similar amounts $(8870 \mathrm{~kg} \mathrm{DM} / \mathrm{ha} / \mathrm{yr})$. Yield advantages of AR37-infected ryegrass were greater at Kerikeri (36\%) than Hamilton $(17 \%)$, with differences increasing over successive years at both sites. At Hamilton, tiller populations were lowest in AR37-infected ryegrass in Year 2, and lowest in AR1infected ryegrass 3 and 5 years after sowing. At both sites AR37-infected ryegrass had the lowest infestation scores for root aphid. At Hamilton in Year 4, more damage by African black beetle larvae occurred to AR1-infected plants than to AR37 and Standard-infected plants. These pests are likely to have contributed to the differences in agronomic performance observed. These agronomic results suggest AR37-infected ryegrass cultivars will be a useful choice for farmers in northern New Zealand.
\end{abstract}

Keywords: endophyte, Neotyphodium lolii, perennial ryegrass, Lolium perenne, dry matter yields, plant persistence, root aphid, Aploneura lentisci, African black beetle, Heteronychus arator

\section{Introduction}

The fungal endophyte (Neotyphodium lolii) that infects perennial ryegrass (Lolium perenne) usually affords this grass increased persistence and productivity (Popay et al. 1999). Much of this, at least in New Zealand, can be attributed to increased protection of endophyte-infected ryegrasses from insect pests (Prestidge et al. 1994; Popay et al. 1999). The northern regions of New Zealand suffer from significant pest pressure with the degree of damage exacerbated when plants are under drought stress in summer and autumn. In particular, this region of New Zealand is prone to periodic attacks from African black beetle (Heteronychus arator). AR37 is a new strain of endophyte that offers ryegrass increased protection from insect damage over that conferred by AR1 and/or Standard endophytes (Popay \& Bonos 2005). To evaluate the agronomic potential of this new strain in northern New Zealand, small plot agronomic trials were sown and evaluated for at least 3 years.

\section{Materials and Methods}

Small plot perennial ryegrass trials were hand-sown into cultivated seedbeds in autumn 2001 at two sites in northern New Zealand. One trial, sown on 16 May 2001, was at the HortResearch site near Kerikeri on an Okaihau gravely clay, a very free-draining volcanic soil, while the other was sown at AgResearch Ruakura, Hamilton, on 8 May 2001 on a Te Rapa peaty silt loam. Soil fertility levels at both sites were capable of sustaining high pasture growth rates (e.g. 40 to $43 \mathrm{ppm}$ Olsen P). Ryegrass was sown at $20 \mathrm{~kg}$ seed/ha and herbicides were used to eliminate or reduce the presence/growth of other species in the plots. $\mathrm{N}$ fertiliser was applied as urea $(46 \% \mathrm{~N})$ after each grazing at the rate of $30 \mathrm{~kg} \mathrm{~N} / \mathrm{ha}$ at Hamilton and $92 \mathrm{~kg} \mathrm{~N} / \mathrm{ha}$ at Kerikeri. During dry periods, $\mathrm{N}$ was withheld and applied before expected rain.

Both sites had four replicates of six treatments laid out in a randomised block design. Plot size was $10.64 \mathrm{~m}^{2}$ at Kerikeri and $16 \mathrm{~m}^{2}$ at Hamilton. Three of the treatments, all in the cultivar 'Grasslands Samson', were the resident common toxic endophyte referred to as Standard (or wild-type), and the selected endophytes AR1 or AR37. The other three treatments were mixtures of Samson AR1 and Samson AR37 in varying ratios (25:75, 50:50, $75: 25)$. This paper does not report the results from these mixture treatments. The sown seed was infected with viable endophyte at frequencies of $96 \%, 82 \%$ and $95 \%$ for AR1, AR37 and Standard, respectively.

Plots were assessed for dry matter yields at Hamilton by cutting two $0.28 \mathrm{~m}^{2}$ quadrats per plot to $2 \mathrm{~cm}$ height, and at Kerikeri by mowing a $4 \mathrm{~m}$ long by $0.53 \mathrm{~m}$ wide strip to $3 \mathrm{~cm}$ height in each plot. The plots were assessed at Hamilton on 27 occasions from September 2001 to September 2005 and at Kerikeri on 22 occasions from October 2001 to November 2004. After each yield assessment, plots were grazed by sheep over a 24 to 48 $\mathrm{h}$ period, with any uneven residuals mown to the average grazing height.

Tiller populations were assessed at Hamilton by counting the number of ryegrass tillers rooted in 15 or 25 cores taken from each plot. Cores $\left(16.64 \mathrm{~cm}^{2}\right)$ were 
Figure 1 Annual ryegrass dry matter yield ( $\mathrm{kg} \mathrm{DM} / \mathrm{ha}$ ) for three endophytes at two sites in northern New Zealand. A full year consists of yields from spring to autumn of the following year. For each year, an error bar shows the LSD value when significant differences occurred $(P<0.05)$.
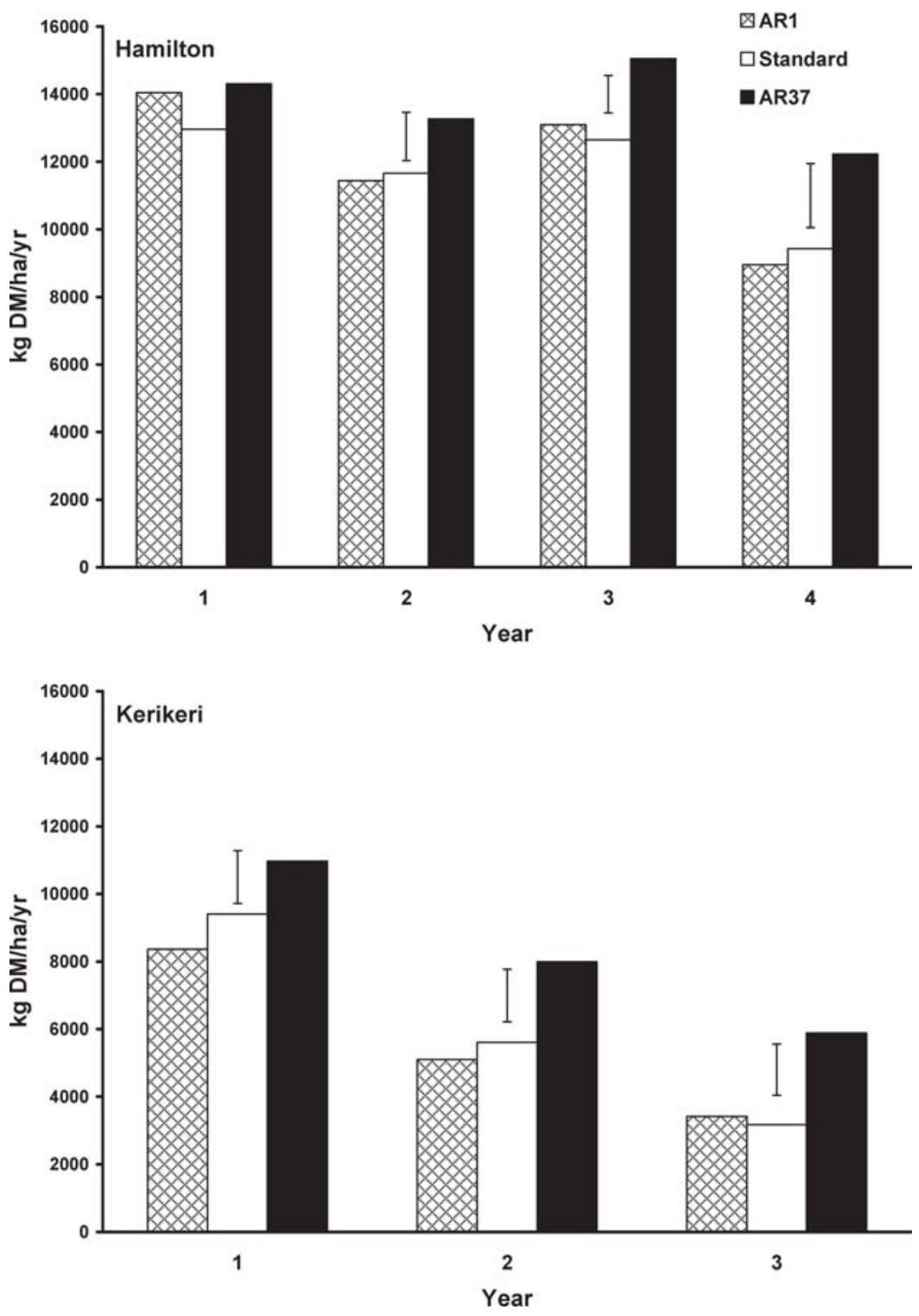

taken in late autumn or winter approximately 2, 3 and 5 years after sowing.

Plots were monitored for the presence of African black beetle and root aphid (Aploneura lentisci), and assessed when populations reached high levels. Root aphids were assessed in autumn approximately 2 years after sowing at Kerikeri (March 2003) and 4 years after sowing at Hamilton (May 2005). Four spade squares $(20 \times 20 \mathrm{~cm}$ to $10 \mathrm{~cm}$ depth) in each plot were given an aphid infestation score based on an estimate of the number of root aphid colonies present. Aphid colonies were identified by the presence of white wax with live root aphid observed amongst the wax. Scores were on a scale of $0-5$, where $0=$ no root aphid colonies visible, $1=1$ -10 colonies, $2=11-20,3=21-30,4=31-40$ and $5=>40$. Black beetle damage was assessed at Hamilton in late summer of Year 4 (February 2005). Ten plants were checked along each of two diagonal transects in each plot. Each plant was pulled firmly. Plants that were firmly rooted were presumed to be undamaged. Those that could be pulled out were checked for symptoms of black beetle larval damage and were recorded as damaged 
if tunnelling, root pruning, frass or larvae were present.

\section{Results}

\section{Annual dry matter yields}

Over the total trial period, AR37 was the highest yielding treatment (mean, $11080 \mathrm{~kg} \mathrm{DM} / \mathrm{ha} / \mathrm{yr}$ ) with 16 and $18 \%$ greater yields at Hamilton and 47 and $37 \%$ greater yields at Kerikeri compared with AR1 and Standard, respectively $(\mathrm{P}<0.05)$. AR1 and Standard had similar $(\mathrm{P}>0.05)$ mean annual yields in all years and at both sites (overall means of 8810 and $8930 \mathrm{~kg} \mathrm{DM} / \mathrm{ha}$, respectively). Relative differences between these endophyte treatments changed with time (Fig. 1). At Hamilton, yields were similar for all endophytes in Year $1(\mathrm{P}>0.05)$, but in Years 2 and 3 AR37 yields were 14 to $19 \%$ higher than AR1 and Standard $(\mathrm{P}<0.05)$, and 30 to $33 \%$ higher in Year $4(\mathrm{P}<0.05)$. Annual yields at Kerikeri were significantly affected by endophyte treatment in all 3 years, with AR37 significantly out-yielding AR1 by $31 \%, 57 \%$ and $72 \%$ in Years 1,2 and 3, respectively $(\mathrm{P}<0.05)$, and Standard by $17 \%, 42 \%$, and $85 \%$, respectively $(\mathrm{P}<0.05)$.

\section{Seasonal dry matter yields}

AR1 and Standard had similar yields $(\mathrm{P}>0.05)$ in all seasons in all years except for summer of Year 1 at Hamilton when AR1 yielded 25\% more than Standard $(\mathrm{P}<0.05)$ (Fig. 2).

The seasonal advantage of AR37 over AR1 or Standard varied with site and year (Fig. 2). At Hamilton, no significant differences $(\mathrm{P}>0.05)$ occurred in Year 1 in any season. In Years 2 to 4 , AR37 out-yielded AR1 $(\mathrm{P}<0.05)$ on 7 of 12 comparisons, mainly during autumn and winter. Over the same period AR37 out-yielded the Standard endophyte on six occasions during the summer to winter period but not in the spring. Seasonal differences were greatest in Year 4 (particularly autumn), being significant $(\mathrm{P}<0.05)$ in three of the four comparisons for AR37 versus either AR1 or Standard. At Kerikeri, significant differences between AR37 and either AR1 or Standard occurred in eight of 12 comparisons during Years 1 to 3. Differences between AR1 and AR37-infected plants were common in spring and autumn whereas differences between AR37 and Standard were more evenly spread throughout the year. The advantage to AR37 occurred more frequently in Years 2 and 3 and was greatest in the summer of Year 3.

\section{Tiller populations}

At Hamilton, ryegrass tiller populations in autumn, 2 years after sowing, were similar for AR1 and Standard (mean $\left.16730 / \mathrm{m}^{2}\right)$, but $13 \%$ lower for AR37 $(\mathrm{P}<0.05)$. Populations in winter, assessed 3 and 5 years after sowing, were similar for Standard and AR37 (mean 10
$380 / \mathrm{m}^{2}$ ), but, respectively, $34 \%$ and $53 \%$ lower in AR1 $(\mathrm{P}<0.05)$.

\section{Insect presence and damage}

Root aphid infestation in Year 2 at Kerikeri and Year 4 at Hamilton was lowest in AR37 plots and highest in AR1 plots ( $\mathrm{P}<0.01$ at Kerikeri; ns at Hamilton) (Table 1). No black beetle damage or larvae were observed in Year 2 at Kerikeri when root aphid was sampled and no damage was apparent in subsequent years. Black beetle damage to the trial at Hamilton was severe in some plots in late summer of Year 4 (Table 1). A significantly higher proportion of plants in AR1 plots were damaged than plants in either Standard or AR37 $(\mathrm{P}<0.05)$.

\section{Discussion}

The high productivity of AR37-infected Samson ryegrass in these trials supports results from similar trials with 'Grasslands Nui' perennial ryegrass (Hume et al. 2004) and two cultivars of Italian ryegrass (L. multiflorum) (Cooper et al. 2006, 2007). The trials with Nui and Italian ryegrass included sites at Kerikeri and Hamilton and a range of endophyte strains. In the Nui evaluations, AR37infected plots were higher yielding than AR1 or Standard in $32 \%$ of comparisons in summer and $53 \%$ in autumn. Similarly for Samson in the current trial, AR37 was higher yielding in $36 \%$ and $71 \%$ of comparisons in summer and autumn, respectively. The increased productivity of AR37-infected Samson, while occurring frequently in summer and autumn, also occurred in winter and spring with AR37 being higher in $57 \%$ and $43 \%$ of these comparisons, respectively. These seasonal effects were also more frequent and greater in magnitude as the trials progressed, similar to those reported by Cooper $e t$ al. (2006, 2007).

One of the notable insect pest resistance attributes of AR37, is its almost complete elimination of root aphid compared with Standard and AR1, while AR1 can have higher infestation levels than Standard (Popay et al. 2004; Pennell et al. 2005; Popay \& Gerard 2007). This effect was particularly evident at Kerikeri in Year 2, with similar trends at Hamilton in Year 4. The presence of root aphid could be linked to yield differences between AR37 and Standard and AR1 in one trial at Lincoln (Pennell et al. 2005). Differences in yield of individual plants in a pot trial were also related to differences in root aphid numbers (Popay \& Gerard 2007). In the trials reported here, root aphid was the only insect pest found in significant (damaging) numbers at Kerikeri with aphid population differences between the endophyte strains corresponding closely with differences in DM yields.

AR37 has provided a similar degree of protection against adult black beetle to the Standard endophyte in 
Figure 2 Relative ryegrass yields for ryegrass infected with AR1 endophyte and AR37 endophyte compared with Standard endophyte $(=100)$ for each season at two sites in northern New Zealand. Error bars show the LSD value when significant differences $(P<0.05)$ occurred between endophyte strains within a season.
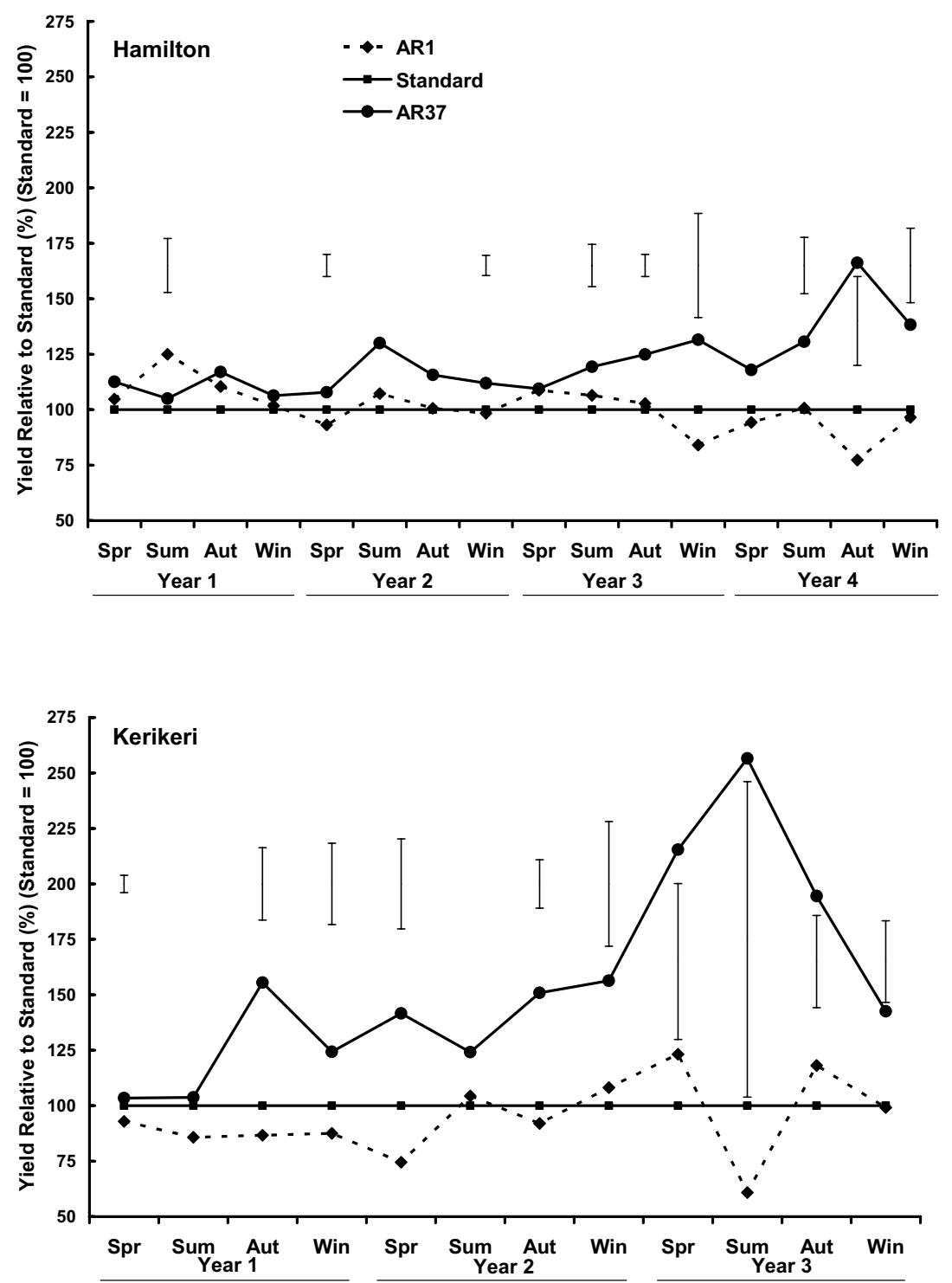

pot trials (Ball et al. 1994) and has reduced larval damage relative to other treatments in field trials with Italian ryegrass at Kerikeri (Cooper et al. 2006). AR1, however, provides only modest protection against black beetle relative to the Standard endophyte (Popay \& Baltus 2001) and to AR37 (A.J. Popay unpublished).

Popay et al. (1999) showed a close correlation between black beetle damage and herbage yields during the period of damage. The same effect was not evident in the Hamilton trial reported in this paper, where, despite AR37 and Standard-infected ryegrass having similar low levels of larval black beetle damage in Year 4, AR37 out-yielded Standard by $31 \%$ in summer and $66 \%$ in autumn. In comparison, AR37 out-yielded AR 1 by 30 to $115 \%$ (summer and autumn, respectively), with Standard yielding $29 \%$ better than AR1 in the autumn although this was a non-significant difference $(\mathrm{P}>0.05)$. This does indicate that the high yields of AR37 at least in Year 4 were due not only to black beetle resistance but also to other factors. The most obvious biotic factor was lower populations of root aphids in AR37 plots. This premise is further supported by tiller populations being 
Table 1 Root aphid infestation score in autumn at Kerikeri in 2003 and Hamilton in 2005, and percentage of plants damaged by black beetle at Hamilton in late summer 2004-05.

\begin{tabular}{|c|c|c|c|}
\hline \multirow[t]{2}{*}{ Treatment } & \multicolumn{2}{|c|}{ Aphid infestation score } & \multirow{2}{*}{$\begin{array}{l}\% \text { Plants with black } \\
\text { beetle damage }\end{array}$} \\
\hline & Kerikeri & Hamilton & \\
\hline AR1 & 3.12 & 3.12 & 29 \\
\hline Standard & 2.25 & 2.38 & 9 \\
\hline AR37 & 0.75 & 1.38 & 8 \\
\hline LSD (5\%) & 1.08 & 1.76 & 16.2 \\
\hline
\end{tabular}

greater in AR37 plots before this black beetle attack and higher yields in AR37 in general over Years 2 and 3, although not as large as the differences that occurred in Year 4. As occurred at Kerikeri, no other insect pests were present in sufficient numbers to explain the yield differences. The greater yield differences between endophyte strains in autumn of Year 4 at Hamilton, may also have been exacerbated by a particularly dry earlymid autumn when only $40 \mathrm{~mm}$ of rain fell compared with a long-term mean of $183 \mathrm{~mm}$.

The results of these field trials confirm a close link between pest pressure and agronomic performance of differing endophyte strains. AR37 will be able to contribute to substantial improvements in the productivity and persistence of ryegrass in these northern sites in New Zealand, when subject to black beetle attack and insidious infestations of root aphid.

\section{ACKNOWLEDGEMENTS}

Kathryn Panckhurst for technical assistance at Kerikeri. Anouck de Bonth, Michael Hickey and Wayne Simpson for endophyte testing.

\section{REFERENCES}

Ball, O.J-P.; Christensen, M.J.; Prestidge, R.A. 1994. Effect of selected isolates of Acremonium endophyte on adult black beetle (Heteronychus arator) feeding. pp. 227-231. In: Proceedings of the 47th New Zealand Plant Protection Conference.

Cooper, B.; Hume, D.; Panckhurst, K.; Popay, A.; Lyons, T. 2006. The role of perennial ryegrass endophyte in Italian ryegrass. Advances in pasture plant breeding. Grassland Research and Practice Series No. 12: 103105.

Cooper, B.M.; Hume, D.E.; Panckhurst, K.A.; Popay, A.J. 2007. Agronomic responses of Italian ryegrasses infected with different Neotyphodium strains. Proceedings of the 6th International Symposium on Fungal Endophytes of Grasses. Grassland Research and Practice Series 13: 297-300.

Hume, D.E.; Popay, A.J.; Cooper, B.M.; Eerens, J.P.J.;
Lyons, T.B.; Pennell, C.G.L.; Tapper, B.A.; Latch, G.C.M.; Baird, D.B. 2004. Effect of a novel endophyte on the productivity of perennial ryegrass (Lolium perenne) in New Zealand. Poster 313. In: Proceedings of the 5th International Symposium on Neotyphodium/ Grass Interactions.

Pennell, C.G.L.; Popay, A.J.; Ball, O.J.-P.; Hume, D.E.; Baird, D.B. 2005. Occurrence and impact of pasture mealybug (Balanococcus poae) and root aphid (Aploneura lentisci) on ryegrass (Lolium spp.) with and without infection by Neotyphodium fungal endophytes. New Zealand Journal of Agricultural Research 48: 329-337.

Popay, A.J.; Baltus, J.G. 2001. Black beetle damage to perennial ryegrass infected with AR1 endophyte. Proceedings of the New Zealand Grassland Association 63: 267-271.

Popay, A.J.; Bonos, S.A. 2005. Biotic Responses in Endophytic Grasses. pp. 163-185. In: Neotyphodium in cool-season grasses. Eds. Roberts, C.A.; West, C.P.; Spiers, D.E. Blackwell Publishing, Ames, IA.

Popay, A.J.; Gerard, P.J. 2007. Cultivar and endophyte effects on a root aphid, Aploneura lentisci, in perennial ryegrass. New Zealand Plant Protection 60: 223-227.

Popay, A.J.; Hume, D.E.; Baltus, J.G.; Latch, G.C.M.; Tapper, B.A.; Lyons, T.B.; Cooper, B.M.; Pennell, C.; Eerens, J.P.J.; Marshall, S.L. 1999. Field performance of perennial ryegrass (Lolium perenne) infected with toxin-free fungal endophytes (Neotyphodium spp.). Ryegrass endophyte: an essential New Zealand symbiosis. Grassland Research and Practice Series 7: 113-122.

Popay, A.J.; Silvester, W.B.; Gerard, P.J. 2004. Effect of different endophyte isolates in perennial ryegrass on a root aphid, Aploneura lentisci. Poster 317. In: Proceedings of the 5th International Symposium on Neotyphodium/Grass Interactions.

Prestidge, R.A.; Popay, A.J.; Ball, O.J-P. 1994. Biological control of pastoral pests using Acremonium spp. endophytes. Proceedings of the New Zealand Grassland Association 56: 33-38. 